\title{
PENERAPAN PEMBELAJARAN BIOLOGI BERBASIS MACROMEDIA FLASH DAN IMPLIKASINYA TERHADAP KETERAMPILAN METAKOGNITIF DAN PENGUASAAN KONSEP SISWA KELAS VIII SMPN 6 MATARAM
}

\author{
Wahyuningsih ${ }^{1}$, Jamaluddin $^{2}$, Karnan $^{2}$ \\ 1) Alumni Pendidikan Biologi FKIP Unram \\ ${ }^{2}$ Dosen Pendidikan Biologi FKIP Unram \\ Email:wahyuningsih@gmail.com
}

\begin{abstract}
Abstrak: Pembelajaran di sekolah umumnya masih mengandalkan bahasa verbal dalam penyampaian materi, sehingga keterampilan berpikir dan hasil belajar siswa menjadi rendah. Salah satu solusinya adalah menggunakan media belajar berbasis audiovisual yang mampu meningkatkan aspek metakognitif dan penguasaan konsep siswa, seperti Macromedia Flash. Penelitian ini bertujuan untuk mengetahui perbedaan keterampilan metakognitif dan penguasaan konsep biologi siswa kelas VIII SMPN 6 Mataram yang menggunakan pembelajaran berbasis Macromedia Flash dengan tanpa Macromedia Flash. Rancangan penelitian ini adalah the static-group comparison design. Hasil penelitian menunjukkan bahwa : 1) siswa yang dibelajarkan dengan Macromedia Flash memiliki nilai rata-rata keterampilan metakognitif yang lebih tinggi daripada siswa yang dibelajarkan tanpa Macromedia Flash, yaitu 85,84 dan 66,80. Berdasarkan hasil uji t diperoleh bahwa terdapat perbedaan keterampilan metakognitif siswa antara kedua kelas tersebut. 2) nilai ratarata penguasaan konsep siswa pada kelas kontrol lebih tinggi daripada kelas eksperimen yaitu sebesar 85,44 dan 84,79. Analisis uji t menunjukkan bahwa tidak terdapat perbedaan penguasaan konsep siswa yang belajar dengan Macromedia Flash dengan siswa yang belajar tanpa Macromedia Flash.
\end{abstract}

Kata kunci: Keterampilan metakognitif, Macromedia Flash, Penguasaan Konsep

\begin{abstract}
Generally in school, the concept delivery in learning process still relies on verbal language, as the result, student's thinking skills and learning outcome become low. Therefore, audiovisual-based learning is needed to improve student's metacognitive and learning outcome aspects, for example by using Macromedia Flash. This research is aimed to differentiate student's metacognitive skills and concept mastery at grade VIII in SMPN 6 Mataram between students who are taught by Macromedia Flash and students who are taught without using Macromedia Flash. This research is included into pre-experimental and the design was the static-group comparison design. The results of this research showed that: 1) students who were taught by Macromedia Flash had average values for metacognitive skils higher than students who were taught without Macromedia Flash, that were 85.84 and 66.80 respectively. From t-test obtained that there was difference of metacognitive skills between both sample groups; 2) the average values of student's concept mastery in control group was higher than students in experimental group, that were 85.44 and 84.79 respectively. T-test analysis indicated that there was no difference of concept mastery between students who were taught by Macromedia Flash and students who were taught without Macromedia Flash.
\end{abstract}

Key words: Metacognitive Skills, Macromedia Flash, Concept Mastery

\section{PENDAHULUAN}

Perkembangan Ilmu Pengetahuan dan Teknologi (IPTEK) sangat pesat era ini dan memberikan pengaruh positif pada bidang pendidikan. Bagi guru, teknologi akan mempermudah dalam penyampaian materi atau konsep dengan berbantuan media pembelajaran. Penggunaan media yang tepat akan memberikan pengalaman belajar yang tepat kepada siswa, sehingga mereka dapat membangun sendiri pengetahuannya tentang suatu konsep. Semakin konkret media yang digunakan, maka pengalaman yang diperoleh siswa akan semakin tinggi. Menurut kerucut pengalaman Edgar Dale [8], siswa yang belajar dengan mengandalkan media berbasis verbal (mendengar) akan memperoleh $20 \%$ pengalaman belajar, sedangkan melalui media visual akan memberikan $30 \%$ pengalaman belajar. Minimnya pengalaman belajar yang diperoleh siswa akan berdampak pada rendahnya kemampuan berpikir dan pengorganisasian proses belajarnya, sehingga akan berdampak pula pada rendahnya penguasaan konsep siswa.

Fakta tersebut masih banyak terlihat di sekolah-sekolah menengah saat ini, seperti SMPN 6 Mataram. Guru masih mengandalkan bahasa verbal dalam penyampaian materi pembelajaran, termasuk pelajaran biologi. Penyampaian materi biologi masih dilakukan tanpa media dan hanya berbantuan papan tulis. Hal itu menyebabkan siswa menganggap bahwa biologi merupakan mata pelajaran hafalan. Dalam belajar menghafal, siswa berusaha menguasai materi tanpa mengetahui maknanya, berbeda dengan belajar bermakna dimana siswa mempelajari suatu materi dengan berusaha memahami makna atau artinya [10]. Belajar dengan menghafal akan membuat siswa menjadi pasif dan tidak dapat meningkatkan keterampilan metakognitif serta penguasaan konsepnya. 
Penggunaan media yang melibatkan audio dan visual merupakan salah satu jawaban untuk meningkatkan kedua aspek penting tersebut. Salah satu media audiovisual yang tepat adalah Macromedia Flash. Macromedia Flash adalah gabungan konsep pembelajaran dengan teknologi audiovisual yang mampu menghasilkan fitur-fitur baru yang dapat menyampaikan materi pelajaran dengan lebih menarik, tidak monoton, dan memudahkan penyampaian [8]. Flash merupakan software berbasis animasi yang juga dilengkapi teks dan audio. Adanya animasi tersebut sangat efektif dalam membantu siswa memahami konsep-konsep abstrak dalam biologi dan mengatur cara belajarnya, seperti merumuskan strategi belajar, merencanakan aktivitas belajar, mengelola informasi hingga mengevaluasi proses belajarnya. Penggunaan Macromedia Flash diharapkan mampu memberikan dampak yang positif bagi peningkatan penguasaan konsep dan keterampilan metakognitif siswa.

Penguasaan konsep terintegrasi melalui kemampuan siswa dalam memahami materi yang dipelajari, menangkap makna konsep dan mampu memecahkan masalah yang terkait dengan konsep tersebut [7]. Keterampilan metakognitif adalah kesadaran berpikir seseorang tentang proses berpikirnya sendiri dan merupakan bentuk kecakapan personal, yaitu kemampuan untuk melihat pada diri sendiri sehingga apa yang dia lakukan dapat terkontrol secara optimal [1,11] sebagaimana dikutip [3] membagi metakognisi menjadi 2 komponen utama, yaitu pengetahuan metakognitif dan regulasi metakognitif. Pengetahuan metakognitif mengacu pada pengetahuan tentang kognitif seperti pengetahuan tentang keterampilan (skill) dan strategi kerja yang baik untuk pebelajar dan bagaimana serta kapan menggunakan keterampilan dan strategi tersebut. Pengetahuan metakognitif dibagi menjadi 3 subkomponen, yaitu pengetahuan deklaratif (declarative knowledge), pengetahuan prosedural (procedural knowledge), dan pengetahuan kondisional (conditional knowledge). Selanjutnya, regulasi metakognitif mengacu pada kegiatankegiatan yang mengontrol pemikiran dan belajar seseorang, yang terbagi menjadi 5 komponen, yaitu perencanaan (planning), strategi manajemen informasi (information management strategies), pengawasan pemahaman (comprehension monitoring), strategi pengkoreksian (debugging strategies) dan penilaian (evaluation) [9].

Berdasarkan hal itu, tujuan penelitian ini adalah untuk mengetahui perbedaan keterampilan metakognitif dan penguasaan konsep siswa yang menggunakan pembelajaran berbasis Macromedia Flash dengan tanpa berbasis Macromedia Flash di kelas VIII SMPN 6 Mataram.

\section{METODE PENELITIAN}

Penelitian ini termasuk pre-experimental dengan desain the static-group comparison yang terdiri atas 1 variabel bebas dan 2 variabel terikat. Variabel bebas adalah penerapan Macromedia Flash, sedangkan variabel terikat yaitu keterampilan metakognitif dan penguasaan konsep siswa. Penelitian dilakukan selama 7 minggu dengan 2 materi, yaitu Sistem Gerak Manusia dan Sistem Peredaran Darah Manusia. Subjek penelitian terdiri dari 2 kelas, yaitu kelas VIII-F sebagai kelas eksperimen dan kelas VIII-A sebagai kelas kontrol. Rancangan penelitian ini disajikan pada tabel 1.

Tabel 1. Desain penelitian

\begin{tabular}{ccc}
\hline Kelas & Perlakuan & Post-test \\
\hline Eksperimen & $\mathrm{X}$ & $\mathrm{O}_{1}$ \\
Kontrol & - & $\mathrm{O}_{2}$ \\
\hline
\end{tabular}

Keterangan:

X : Pembelajaran dengan Macromedia Flash

- : Pembelajaran tanpa Macromedia Flash

$\mathrm{O}_{1}$ : Hasil post-test kelas eksperimen

$\mathrm{O}_{2}$ : Hasil post test kelas kontrol

$\begin{array}{ccr}\text { Pengumpulan } & \text { data } & \text { keterampilan } \\ \text { metakognitif dilakukan } & \text { dengan } & \text { inventori }\end{array}$ keterampilan metakognitif (MAI). Inventori ini terdiri atas 52 item pernyataan dengan pilihan jawaban benar-salah [9]. MAI yang digunakan adalah hasil terjemahan ke dalam bahasa Indonesia yang telah diuji hasil terjemahannya. Data penguasaan konsep siswa diukur menggunakan tes pilihan ganda yang diuji validitas dan reliabilitasnya dengan rumus koefisien Point Biserial dan rumus KR-20.

Data post test dianalisis menggunakan uji $\mathrm{t}$ dengan rumus polled varians dan separated varians. Sebelum analisis hipotesis, data penguasaan konsep dan keterampilan metakognitif dilakukan uji normalitas dengan rumus Chi Kuadrat dan uji homogenitas dengan uji F.

\section{HASIL DAN PEMBAHASAN}

Hasil tes akhir (post test) keterampilan metakognitif siswa merupakan hasil rata-rata dari nilai dua materi yang diajarkan. Rata-rata skor post test keterampilan metakognitif siswa disajikan pada tabel 2. Berdasarkan tabel 2, terlihat bahwa keterampilan metakognitif siswa pada kelas eksperimen yang diajarkan dengan Macromedia Flash memiliki skor rata-rata lebih tinggi dibandingkan dengan kelas tanpa Macromedia Flash. 
Tabel 2. Nilai rata-rata keterampilan metakognitif

\begin{tabular}{cc}
\hline Perlakuan & Skor Pos-test \\
\hline Eksperimen & 85.84 \\
Kontrol & 66.80 \\
\hline
\end{tabular}

Visualisasi rata-rata skor kedua kelas tersebut disajikan pada Gambar 1.

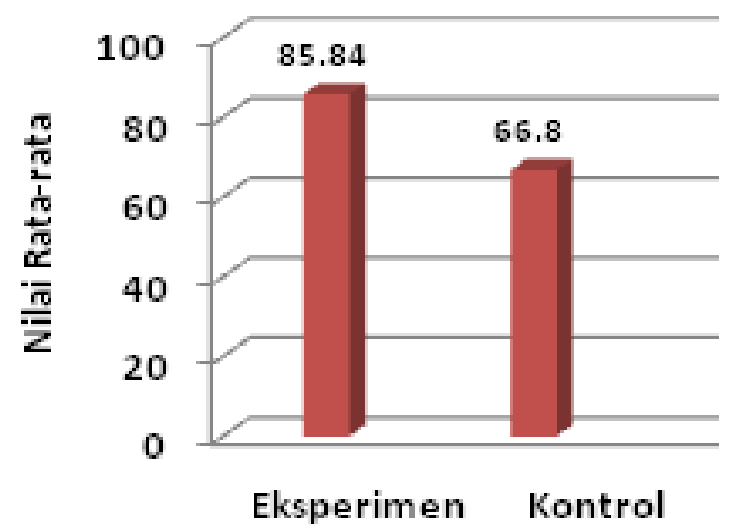

Gambar 1. Histogram nilai rata-rata keterampilan metakognitif siswa kelas eksperimen dan kelas kontrol

Hasil uji normalitas data keterampilan metakognitif kelas eksperimen menghasilkan $\chi^{2}$ hitung $<\chi_{\text {tabel }}^{2}(8.91<11.07)$ yang berarti data terdistribusi normal, sedangkan kelas kontrol dengan hasil $\quad \chi_{\text {hitung }}^{2}>\chi_{\text {tabel }}^{2}(20.67>11.07)$ artinya data tidak terdistribusi normal. Hasil uji homogenitas diperoleh $F_{\text {hitung }}>\mathrm{F}_{\text {tabel }}(2.54>1.81)$ yang artinya varians heterogen. Hasil uji t data keterampilan metakognitif diperoleh $t_{\text {hitung }}>t_{\text {tabel }}(7.957>2.038)$ yang artinya Ho ditolak dan Ha diterima.

Hasil uji $t$ tersebut menunjukkan ada perbedaan keterampilan metakognitif siswa yang diajar menggunakan Macromedia Flash dengan siswa yang diajar tanpa Macromedia Flash. Hal tersebut mengindikasikan bahwa Macromedia Flash memberikan kontribusi yang positif terhadap peningkatan keterampilan metakognitif siswa. Terdapat beberapa faktor yang mempengaruhinya, antara lain 1) tayangan slide Macromedia Flash menampilkan animasi awal berisi materi apersepsi yang dikaitkan dengan materi sebelumnya. Dengan begitu, siswa akan dapat me-review konsep yang telah dipelajari sebelumnya dan menyusun konsep yang belum dia ketahui dan ingin dia ketahui dari materi selanjutnya yang akan dipelajari. Hal tersebut merupakan bagian dari keterampilan metakognitif dalam merencanakan proses dan strategi untuk belajar. 2) Macromedia Flash memiliki tampilan yang menarik ditambah dengan animasi yang sesuai dengan kebutuhan materi. Dengan demikian, siswa langsung tertarik untuk mengikuti pelajaran dan lebih cepat mengerti, mampu mengelola informasi yang ditampilkan dengan lebih mudah, sekaligus dapat menemukan strategi belajar baru untuk mereka terapkan, misalnya belajar melalui media berbasis animasi. 3) Macromedia Flash memiliki tomboltombol icon berupa submateri yang akan dibahas sesuai urutannya. Dengan adanya icon-icon tersebut, materi yang akan dibahas lebih terstruktur dan berurutan, sehingga siswa lebih mudah mengelola informasi dan memonitor proses belajar dalam memahami semua materi tersebut. 4) Macromedia Flash dilengkapi dengan tes atau games interaktif yang menarik untuk siswa. Ketika pembelajaran selesai, siswa akan mencoba tes atau games tersebut dan langsung mengetahui skor yang diperoleh dan letak kesalahannya dalam menjawab. Dengan adanya fitur tersebut, siswa mampu mengevaluasi sendiri proses belajarnya, apakah telah efektif atau belum atau apakah hasilnya telah maksimal atau tidak. Selain itu, siswa dapat mengetahui letak kesalahan strategi belajarnya dan dapat mengoreksi serta mengubah strateginya agar lebih efektif dalam memahami konsep dengan baik.

Analisis terhadap skor subkomponen keterampilan metakognitif menunjukkan skor yang berbeda antara kedua kelas. Nilai rata-rata keterampilan metakognitif yang lebih tinggi pada kelas eksperimen mengindikasikan bahwa nilai subkomponennya juga lebih tinggi dibandingkan kelas kontrol. Skor perolehan subkomponen metakognitif kedua kelas disajikan pada tabel 3.

Tabel 3. Nilai rata-rata subkomponen keterampilan metakognitif

\begin{tabular}{ccccccccc}
\hline Kelas & DK & PK & CK & Pl & IMS & CM & DS & Ev \\
\hline \multirow{2}{*}{$\mathrm{X}$} & 6.56 & 3.57 & 4.32 & 6.20 & 8.53 & 5.93 & 4.44 & 5.17 \\
\cline { 2 - 10 } & 8 & 4 & 5 & 7 & 10 & 7 & 5 & 6 \\
\hline \multirow{2}{*}{$\mathrm{O}$} & 4.99 & 2.52 & 3.60 & 4.86 & 6.71 & 4.66 & 3.66 & 3.77 \\
\cline { 2 - 9 } & & & & & & & & \\
\end{tabular}

Keterangan Tabel 3: X : Kelas Eksperimen, O: Kelas Kontrol, DK: Declarative Knowledge (Pengetahuan Deklaratif), PK: Procedural Knowledge (Pengetahuan Prosedural), CK: Conditional Knowledge (Pengetahuan Kondisional), Pl: Planning (Perencanaan), IMS: Information Management Strategies (Strategi Pengelolaan Informasi), CM: Comprehension Monitoring (Pengawasan Pemahaman), DS: Debugging Strategies (Strategi Pengkoreksian), Ev: Evaluation (Evaluasi) 


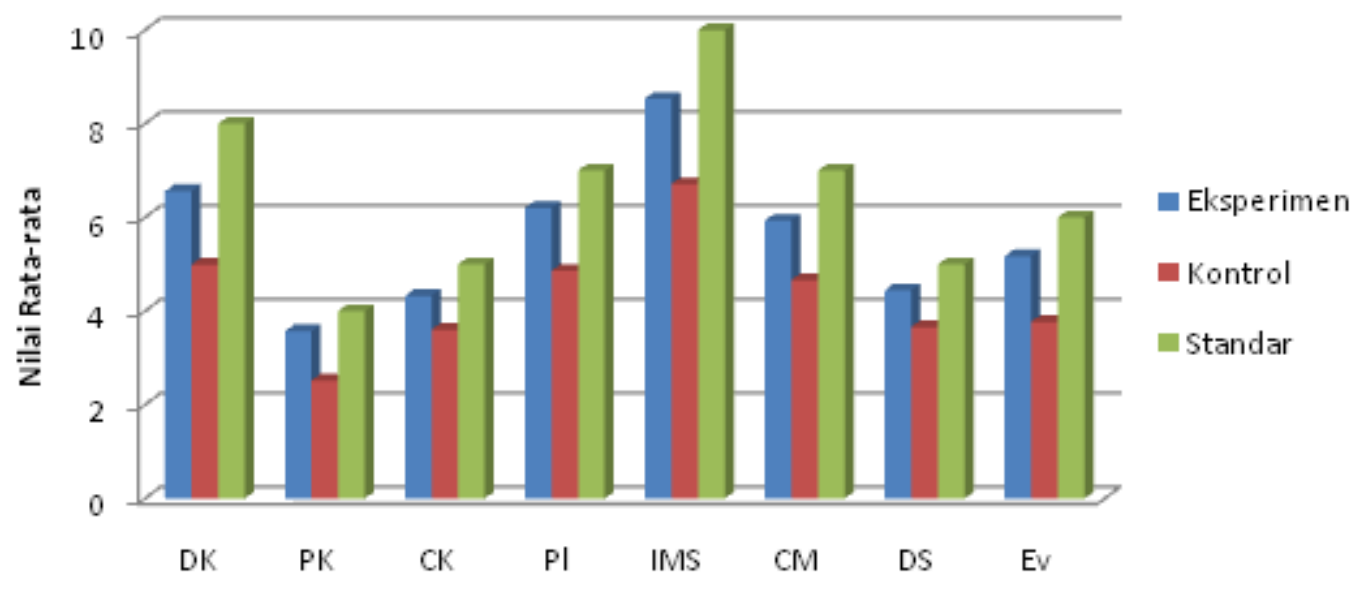

Subkomponen Keterampilan Metakognitif

Gambar 2. Histogram nilai rata-rata subkomponen keterampilan metakognitif siswa kelas eksperimen dan kelas kontrol

Berdasarkan tabel 3 di atas, terlihat bahwa skor tiap subkomponen metakognitif mulai dari declarative knowledge hingga evaluation menunjukkan skor yang lebih tinggi pada kelas ekperimen dibandingkan kelas kontrol. Namun, skor tersebut belum mencapai standar skor per subkomponen. Visualisasi perbandingan skor subkomponen metakognitif kelas ekperimen dan kelas kontrol ditampilkan pada Gambar 2.

Hasil yang maksimal pada keterampilan metakognitif secara keseluruhan, juga mengindikasikan perolehan yang maksimal pada subkomponennya. Berdasarkan hasil penelitian terhadap subkomponen keterampilan metakognitif, terlihat bahwa skor rata-rata subkomponen kelas eksperimen lebih tinggi daripada kelas kontrol. Artinya, pembelajaran dengan Macromedia Flash dapat memberikan pengaruh positif bagi peningkatan skor subkomponen metakognitif. Keunggulan Macromedia Flash dalam peningkatan subkomponen-subkomponen tersebut antara lain: 1) Pada subkomponen declarative knowledge, kelas eksperimen memiliki nilai yang lebih tinggi dibandingkan kelas kontrol. Hal ini erat kaitannya dengan hadirnya slide Flash yang memunculkan konsep sebelumnya yang dikaitkan dengan konsep yang akan dipelajari. Dengan demikian, siswa menjadi tahu apa yang dia ketahui dan belum dia ketahui, dapat merumuskan strategi untuk menguasai konsep tersebut, serta menemukan sumber belajar untuk mendukung pencapaian tujuannya. 2) Subkomponen kedua yaitu procedural knowledge, yang juga memiliki skor lebih tinggi pada kelas eksperimen. Hal ini berkaitan dengan subkomponen sebelumnya, yaitu bagaimana menggunakan strategi dan keterampilan serta pengetahuan yang telah diketahui sebelumnya dan mengaplikasikannya dalam mempelajari konsep selanjutnya. Artinya, karena siswa kelas eksperimen telah mengetahui hal- hal yang belum dan sudah mereka ketahui, jadi mereka dapat dengan mudah menggunakannya pada proses pembelajaran yang akan dilakukan. 3) Pada subkomponen conditional knowledge, kelas eksperimen dengan bantuan media Macromedia Flash lebih unggul dalam mengatur kapan dan mengapa siswa menggunakan keterampilan dan strategi yang diperoleh sebelumnya. Hal itu disebabkan dalam Flash siswa diajarkan berpikir terstruktur dengan mempelajari konsep secara berurutan dari satu konsep menuju konsep selanjutnya. 4) Subkomponen planning, information management strategies, dan comprehension monitoring menunjukkan skor yang juga lebih tinggi pada kelas eksperimen dibandingkan kelas kontrol. Hal itu terkait dengan adanya icon-icon submateri pada Macromedia Flash yang tersusun sistematis, sehingga siswa mampu merencanakan proses belajarnya dan memonitor pemahamannya dengan baik. Adanya animasi juga mampu meningkatkan kemampuan siswa dalam mengelola informasi yang disampaikan oleh guru, sehingga lebih mudah dimengerti. 5) Peningkatan nilai pada subkomponen debugging strategies dan evaluation terkait dengan hadirnya fitur tes atau games interaktif. Games interaktif yang dimiliki oleh Flash ini mengkondisikan siswa dapat menguji pemahamannya tentang konsep yang telah dipelajari dan membiarkan Flash tersebut mengkoreksi jawabannya dan menginformasikan letak kesalahannya. Dengan demikian, siswa mampu mengecek pemahamannya tentang suatu konsep dan dapat memperbaiki (mengkoreksi) pemahaman yang salah tentang konsep tersebut. Pada tahap evaluasi, siswa akan memilih, apakah akan mengubah strategi belajar awal yang digunakannya, tetap mempertahankannya atau menyerah pada keadaan. Melalui games interaktif tersebut, siswa mempunyai kesempatan untuk dapat memperoleh hasil yang maksimal. Jadi, Flash akan menuntun siswa yang awalnya salah konsep agar 
dapat memperbaikinya dan selanjutnya dapat menentukan strategi belajar yang lebih efektif bagi mereka masing-masing.

Di samping nilai keterampilan metakognitif, tes akhir (post test) juga dilakukan untuk mengukur penguasaan konsep siswa. Data perolehan nilai ratarata post test penguasaan konsep siswa dipaparkan pada tabel 4.

Tabel 4. Nilai rata-rata penguasaan konsep

\begin{tabular}{cc}
\hline Perlakuan & Skor Pos-test \\
\hline Eksperimen & 84.79 \\
Kontrol & 85.44 \\
\hline
\end{tabular}

Berdasarkan data tabel 4, secara deskripsi menunjukkan bahwa penguasaan konsep siswa pada kelas kontrol (tanpa Macromedia Flash) memiliki nilai rata-rata yang lebih tinggi daripada kelas eksperimen yang diajar dengan Macromedia Flash. Selisih kedua nilai tersebut sangat sedikit, yaitu nilai kelas kontrol 0.65 poin lebih tinggi daripada kelas eksperimen. Visualisasi nilai rata-rata kedua kelas tersebut diperlihatkan pada Gambar 3.

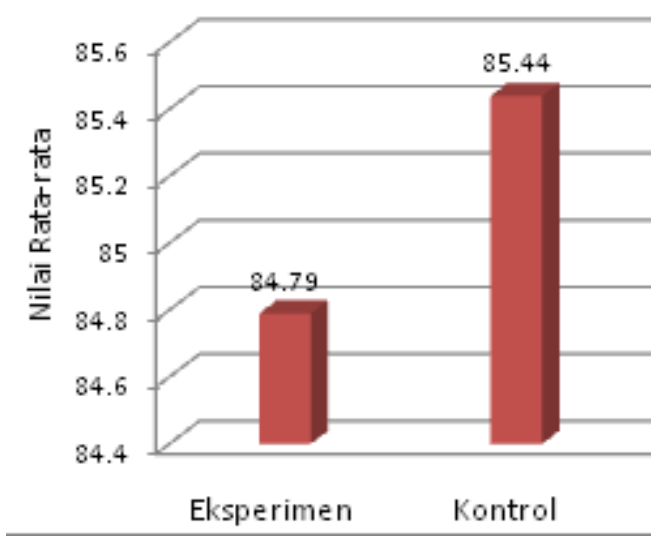

Gambar 3. Histogram nilai rata-rata penguasaan konsep siswa kelas eksperimen dan kelas kontrol

Hasil uji normalitas data penguasaan konsep kelas eksperimen menunjukkan $\chi_{\text {hitung }}^{2}>\chi^{2}$ tabel (46.80 > 11.07), sehingga data tidak terdistribusi normal. Uji normalitas data penguasaan konsep kelas kontrol menghasilkan $\chi_{\text {hitung }}^{2}<\chi_{\text {tabel }}^{2}(5.40<$ 11.07) yang artinya data terdistribusi normal. Hasil uji homogenitas data penguasaan konsep menunjukkan $F_{\text {hitung }}<F_{\text {tabel }}(1.00<1.82)$ yang berarti varians data homogen. Analisis uji t data penguasaan konsep menunjukkan $t_{\text {hitung }}<t_{\text {tabel }}(0.356<1.998)$ sehingga diperoleh Ho diterima dan Ha ditolak.

Analisis uji $t$ nilai penguasaan konsep tersebut menunjukkan bahwa tidak ada perbedaan penguasaan konsep siswa yang diajar menggunakan Macromedia Flash dengan tanpa Macromedia Flash di kelas VIII SMPN 6 Mataram. Tidak adanya perbedaan ini menunjukkan bahwa Macromedia Flash tidak dapat memberikan kontribusi yang kuat dan positif bagi penguasaan konsep siswa. Terdapat beberapa faktor yang mempengaruhi hal tersebut, antara lain: 1) Macromedia Flash yang digunakan merupakan media jadi (siap pakai), sehingga memiliki keterbatasan dan sulit menyesuaikan dengan kebutuhan siswa setempat. Sebagaimana disebutkan [7] bahwa kekurangan media jadi adalah kecilnya kemungkinan untuk mendapatkan media jadi yang sepenuhnya dapat sesuai dengan tujuan atau kebutuhan pembelajaran setempat. Padahal, keberhasilan proses pembelajaran dipengaruhi oleh penggunaan media yang sesuai dengan tujuan tertentu [4]. Artinya, media yang disiapkan guru hendaknya memenuhi kebutuhan siswa di tempat itu demi pencapaian keberhasilan pembelajaran. Kekurangan dalam Flash jadi yang dipakai antara lain submateri yang tidak semuanya tercakup dalam Flash, animasi terbatas, penjelasan didominasi audio, dan durasi animasi serta audio terlalu cepat. Hal tersebut menyebabkan siswa kurang dapat menangkap makna konsep secara maksimal. 2) Penerapan Flash masih baru bagi siswa, sehingga masih sulit beradaptasi. Terjadinya perubahan gaya belajar yang mendadak menyebabkan siswa kurang dapat beradaptasi menerima dan memproses informasi yang disampaikan Flash. 3) Penguasaan guru dalam menggunakan Flash masih kurang. Hal ini didukung dengan hasil observasi oleh pengamat terhadap keterlaksanaan langkah pembelajaran yang hasilnya belum maksimal atau $100 \%$ terlaksana oleh guru. Guru belum dapat berimprovisasi dengan leluasa menggunakan Flash, sehingga penerimaan konsep siswa pun kurang. 4) Adanya animasi pada Flash di samping menarik perhatian siswa, ternyata juga mengalihkan fokus siswa pada animasi, bukan pada isi materi. Hal tersebut menyebabkan siswa lebih tertarik memainkan ulang animasi daripada memahami konsep yang disampaikan animasi.

Nilai rata-rata penguasaan konsep pada kelas kontrol yang menggunakan media non-Flash atau menggunakan Power Point lebih tinggi daripada kelas eksperimen antara lain disebabkan oleh : 1) Media kelas kontrol dibuat sendiri oleh guru (peneliti) sehingga semua materi sudah tercakup dalam media. 2) Guru dapat berimprovisasi dengan leluasa menggunakan media tersebut karena sudah dikuasai dan merupakan hasil buatan sendiri. 3) media Power Point tidak memiliki animasi gambar bergerak, melainkan hanya gambar diam, sehingga perhatian siswa dapat terfokus pada isi materi dan penjelasan guru. Power Point juga tidak memiliki audio penjelasan sendiri, sehingga guru dapat menjelaskan langsung dengan bahasa yang dapat dimengerti siswa. Dengan demikian, penguasaan konsep siswa akan meningkat.

Berdasarkan hasil penelitiannya, perolehan skor rata-rata keterampilan metakognitif siswa sejalan dengan skor rata-rata penguasaan konsep. Artinya, apabila skor keterampilan metakognitif tinggi, maka skor penguasaan konsep juga akan 
tinggi [3]. Hal tersebut sesuai dengan hasil penelitian dan pembahasan yang telah dijabarkan di atas, dimana skor rata-rata baik penguasaan konsep maupun keterampilan metakognitif siswa kelas VIII SMPN 6 Mataram tergolong tinggi setelah diberikan perlakuan pembelajaran dengan Macromedia Flash. Terlepas dari media mana yang lebih tinggi perolehan nilai akhirnya, kedua media tersebut sangat efektif dalam meningkatkan penguasaan konsep sekaligus keterampilan metakognitif siswa.

\section{KESIMPULAN}

1. Macromedia Flash memberikan kontribusi yang positif terhadap peningkatan keterampilan metakognitif siswa kelas VIII SMPN 6 Mataram. Hal itu ditunjukkan dengan nilai rata-rata kelas eksperimen yaitu 85.84 yang lebih tinggi daripada kelas kontrol yaitu 66.80 dan hasil analisis uji t yang diperoleh dimana Ho ditolak dan Ha diterima.

2. Macromedia Flash tidak memberikan kontribusi yang positif terhadap nilai penguasaan konsep siswa kelas VIII SMPN 6 Mataram. Hal itu ditunjukkan dengan nilai rata-rata kelas eksperimen yaitu 84.79 yang lebih rendah daripada kelas kontrol yaitu 85.44 dan hasil analisis uji t yang diperoleh yaitu Ho diterima dan Ha ditolak.

\section{SARAN}

Berdasarkan hasil penelitian ini, maka disarankan: 1) Guru hendaknya mencoba mengaplikasikan media Macromedia Flash yang dibuat atau dikembangkan sendiri dalam rangka meningkatkan penguasaan konsep dan keterampilan metakognitif siswa dengan maksimal. 2) Hendaknya siswa/pelajar dapat memberikan respon yang baik terhadap penerapan media pembelajaran Macromedia Flash walaupun masih bersifat baru. Selain itu, siswa hendaknya mengisi inventori keterampilan metakognitif dengan baik dan jujur agar data yang diperoleh murni sesuai keadaan yang sebenarnya. 3) Peneliti lain dapat menggunakan hasil penelitian ini sebagai referensi atau rujukan dengan mengembangkan aspek-aspek yang belum diungkap dan dicapai dari penelitian ini. Peneliti selanjutnya juga dapat mencoba memadukan Macromedia Flash hasil buatan sendiri dengan model pembelajaran yang mengutamakan aktivitas siswa, seperti PBL dan Inquiry dalam meningkatkan keterampilan metakognitif siswa.

\section{DAFTAR PUSTAKA}

[1] Aziz, T.A. 2008. Pembelajaran Matematika dengan Model Advance Organizer untuk Meningkatkan Kemampuan Metakognisi Siswa SMA. Skripsi. Bandung: Universitas Pendidikan Indonesia.
[2] Campbell D.T. \& Stanley J.C. 1963. Experimental and Quasi-Experimental Designs for Research. Hopewell, NJ: Houghton Mifflin Company.

[3] Danial, M. 2010. Menumbuhkembangkan Kesadaran dan Keterampilan Metakognisi Mahasiswa Jurusan Biologi melalui Penerapan Strategi PBL dan Kooperatif GI. Jurnal FMIPA Kimia: 111.

[4] Lutfi, A., Siti T., dan Suyono. 2007. Penggunaan Program SPSS sebagai Penunjang Perkuliahan Statistik Dasar pada Mahasiswa Jurusan Kimia FMIPA Unesa. Jurnal Penelitian Pendidikan Matematika dan Sains: Vol. 14 No. 2: 83-88.

[5] Maizora, S. 2011. Pembuatan Media Pembelajaran dengan Macromedia Flash 8.0. (online). http://syafdiichiemaizora.files.wordpress.c om/2011/01/ pengenalan-flash.pdf, Diakses tanggal 27 Maret 2013.

[6] Nurjanah, S.I., Suwarto WA, dan Idam Ragil WA. 2012. Model Kooperatif Tipe TGT untuk Meningkatkan Pemahaman Konsep Koperasi pada Mata Pelajaran IPS. Jurnal FKIP PGSD: 1-7.

[7] Sadiman, A.S., R. Rahardjo, A. Haryono, dan Rahardjito. 1986. Media Pendidikan: Pengertian, Pengembangan dan Pemanfaatannya. Jakarta: PT. RajaGrafindo Persada.

[8] Sanjaya. 2010. Perencanaan dan Desain Sistem Pembelajaran. Jakarta: Kencana Prenada Media Group.

[9] Schraw, G. \& Dennison, R.S. (1994). Assesing Metacognitive Awareness. Contemporary Educational Psychology, 19: 460-475.

[10] Sukmadinata, N. S. 2002. Pengembangan Kurikulum: Teori dan Praktek. Bandung: PT. Remaja Rosdakarya.

[11] Syaiful. 2011. Metakognisi Siswa dalam Pembelajaran Matematika Realistik di Sekolah Menengah Pertama. Jurnal Edumatica: Vol. 1 No. 2: 1-13. 